\title{
Nosocomial diarrhoea in relation to sanitation state: a study in Tikrit, Iraq
}

\author{
S.B. Alrifai, ${ }^{1}$ A. Al Saadi ${ }^{2}$ and Y.A. Mahmood ${ }^{3}$
}

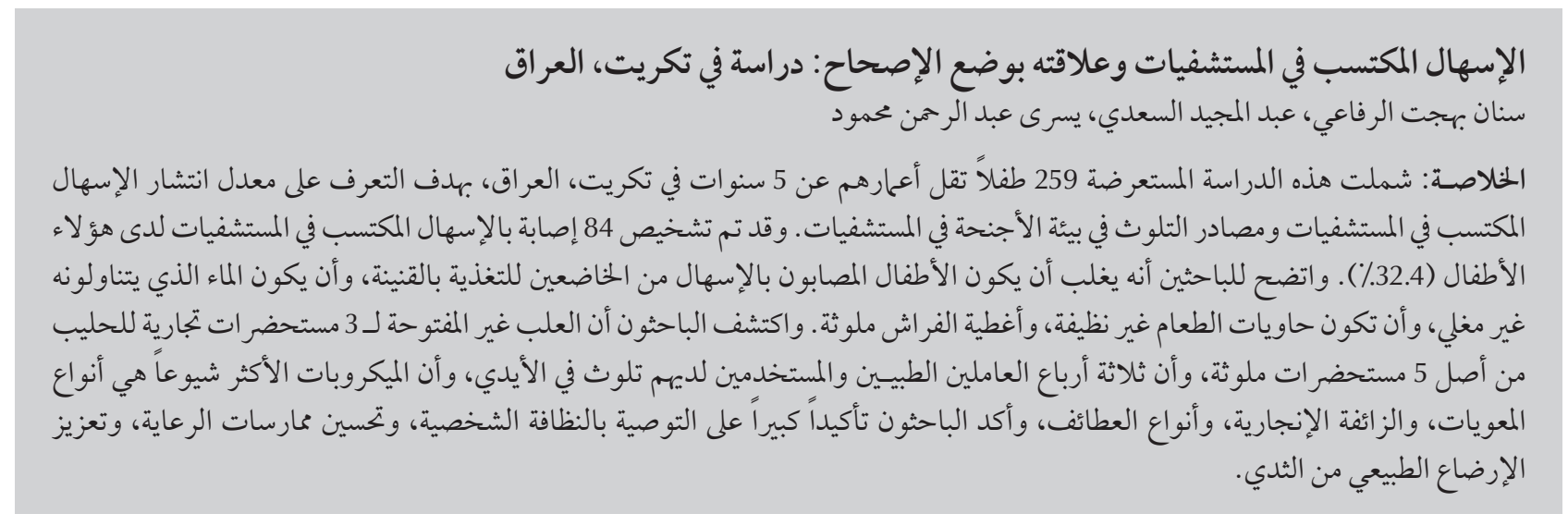

ABSTRACT A cross-sectional hospital-based study of 259 children aged $<5$ years was carried out in Tikrit, Iraq, to identify the prevalence of nosocomial diarrhoea and sources of contamination in the ward environment. Nosocomial diarrhoea was diagnosed in 84 children (32.4\%). Children with diarrhoea were more likely than unaffected children to be bottle-fed, given unboiled water, to have unclean food containers and contaminated bed sheets. Three out of 5 brands of formula milk (unopened cans) were contaminated. Three-quarters of medical staff and employees had contaminated hands. Enterobacter spp., Pseudomonas aeruginosa and Citrobacter spp. were the most commonly identified microorganisms. A greater emphasis on personal hygiene, improved care practices and promotion of breastfeeding is recommended.

\section{Diarrhée nosocomiale en rapport avec l'état de l'assainissement : étude conduite à Tikrit (Iraq)}

RÉSUMÉ Une étude transversale a été réalisée à l'hôpital universitaire de Tikrit sur 259 enfants de moins de 5 ans, afin de déterminer la prévalence de la diarrhée nosocomiale et les sources de contamination dans les services hospitaliers. Une diarrhée nosocomiale a été diagnostiquée chez 84 enfants $(32,4 \%)$. Les enfants atteints de diarrhée étaient plus susceptibles que ceux qui n'en souffraient pas d'être nourris au biberon, de boire de l'eau non bouillie, de manger dans des récipients mal nettoyés et de dormir dans des draps contaminés. Trois des cinq marques de lait pour nourrissons (boîtes non ouvertes) étaient contaminées. Les trois quarts du personnel médical et des employés avaient les mains contaminées. L'Enterobacter spp., le Pseudomonas aeruginosa et le Citrobacter spp. ont été les micro-organismes les plus fréquemment identifiés. Il est recommandé d’accorder plus d'importance à l'hygiène personnelle, d'améliorer les pratiques en matière de soins et de favoriser l'allaitement.

${ }^{7}$ Department of Medical Microbiology; ${ }^{3}$ Department of Medical Education, College of Medicine, University of Tikrit, Tikrit, Iraq . ${ }^{2}$ Department of Bacteriology and Immunology, College of Science, University of Kufa, Najaf, Iraq (Correspondence to Y.A. Mahmood: yousramahmood2003@yahoo.com).

Received: 23/09/07; accepted: 09/04/08 


\section{Introduction}

Infectious diarrhoea is a common condition resulting in considerable morbidity and economic loss [1]. The rates of nosocomial (hospital-acquired) infections are markedly higher in many developing countries because of lack of staff supervision, poor prevention practices, inappropriate use of limited resources and overcrowding in hospitals [2]. Nosocomial infections result from the interaction of several factors: microorganisms in the hospital environment, the compromised (or weakened) status of the patient and the chain of transmission in the hospital [3].

Where person-to-person spread is particularly efficient, eradication of an infectious disease is more difficult [4]. However, nosocomial transmission of fecal organisms by contaminated food or water can be reduced considerably by improving sanitation, food handling and staff hygiene, including handwashing or the use of waterless, alcohol-based handrub products [2]. The organisms causing most nosocomial infections usually come from the patient's own body (endogenous flora). They also can come from contact with staff (crosscontamination), contaminated instruments and needles and the environment (exogenous flora) [2].

Nosocomial diarrhoea is a serious problem in hospitals in Iraq. This study in Tikrit was performed to measure the prevalence of nosocomial diarrhoea among children aged under 5 years and to identify likely sources of contamination in the paediatric ward environment.

\section{Methods}

A cross-sectional hospital-based study was carried out at Tikrit teaching hospital from October 2004 to the end of September 2005. The study included all 259 children $<5$ years of age admitted to the paediatric ward during the study period for reasons other than diarrhoea and hospitalized for more than 3 days in the hospital before any complaint of diarrhoea. The patients were divided into 2 groups for analysis: children who developed nosocomial diarrhoea and those who did not.

Data were collected for each child on: type of feeding (breastfed, bottle-fed or mixed); the source of water given to the child (hospital municipal supply, water brought from the patient's home supply or bottled commercial water) and whether it was boiled or not; the cleanliness of the child's food containers, clothes and bedsheets; and the use of a pacifier (as a risk of cross-infection).

Stool samples were taken from all children who developed diarrhoea 3 days or more after admission, i.e. a change in frequency and/or consistency of stool according to the Centers for Disease Control and Prevention definition [5]. All fecal specimens were subjected to several diagnostic laboratory tests for detection of viral, bacterial, parasitic and fungal agents. These tests include general stool examination, latex agglutination test for detection of human rotavirus antigen, enzyme-linked immunosorbent assay (ELISA) for detection of Clostridium difficile toxins in stool and cultivation on culture media for bacterial and fungal isolation. Identification of the bacterial isolates was based on biochemical tests, the Analytical Profile Index (API 20E) system and finally by specific agglutinating antisera.

Swabs were taken from various objects, people and locations in the hospital environment: personal objects related to the child (bottle teat, pacifier, water container, bedsheet, cannula); the mother (hands, clothes); medical personnel in the ward, including doctors, nurses, cleaners, reception and administration staff, food handlers and medical students (hands, oral cavity); personal objects related to staff (stethoscope); and rooms in the paediatric ward (floors, doorknobs, desks). Analysis was also made of samples of water from the hospital municipal supply and from tins of powdered formula milk. The formula milk samples were taken from sealed cans that were opened under aseptic laboratory conditions.

Isolation and identification of Gram-negative bacilli were performed by conventional methods.

Statistical analyses were performed with the SPSS program, using the chisquared test. $P<0.05$ was considered statistically significant.

\section{Results}

\section{Prevalence of nosocomial diarrhoea}

A total of 259 hospitalized children $<5$ years of age were included in the study. Of these, 84 children (32.4\%) developed nosocomial diarrhoea.

\section{Contamination in relation to infant feeding}

Among 69 children with nosocomial diarrhoea aged $<2$ years, 61 were fed milk and among 124 unaffected children aged $<2$ years, 101 were milk-fed. Only $26.2 \%(16 / 61)$ of children $<2$ years who developed nosocomial diarrhoea were exclusively or predominantly breastfeeding compared with $52.5 \%$ $(53 / 101)$ of the unaffected children $\left(\chi^{2}\right.$-test, $\left.P<0.05\right)$. Similarly, $52.5 \%$ $(32 / 61)$ of the children $<2$ years who developed nosocomial diarrhoea were bottle-fed in comparison with $24.8 \%$ $(25 / 101)$ of the unaffected children $\left(\chi^{2}\right.$-test, $\left.P<0.05\right)$. Similar proportions of affected and unaffected children had mixed feeding.

There were only 8 children who were exclusively breastfed and the remaining 251 were given water. Table 1 shows that most of these children (59.0\%) were given water to drink from their home municipal supply, $12.4 \%$ drank the hospital municipal water and 28.7\% drank commercial bottled water. Among children with nosocomial diarrhoea, $42.9 \%$ of them were given water 


\begin{tabular}{|c|c|c|c|c|c|c|}
\hline \multirow[t]{2}{*}{ Source/treatment of water } & \multicolumn{2}{|c|}{$\begin{array}{l}\text { Children with nosocomial } \\
\text { diarrhoea }(n=84)\end{array}$} & \multicolumn{2}{|c|}{$\begin{array}{l}\text { Unaffected children } \\
\qquad(n=167)\end{array}$} & \multicolumn{2}{|c|}{$\begin{array}{l}\text { Total } \\
(n=251)^{\mathrm{a}}\end{array}$} \\
\hline & No. & $\%$ & No. & $\%$ & No. & $\%$ \\
\hline \multicolumn{7}{|l|}{ Hospital } \\
\hline Boiled & 2 & 2.4 & 22 & 13.2 & 24 & 9.6 \\
\hline Unboiled & 4 & 4.8 & 3 & 1.8 & 7 & 2.8 \\
\hline \multicolumn{7}{|l|}{ Home (municipal) } \\
\hline Boiled & 33 & 39.3 & 79 & 47.3 & 112 & 44.6 \\
\hline Unboiled & 20 & 23.8 & 16 & 9.6 & 36 & 14.3 \\
\hline \multicolumn{7}{|l|}{ Commercial bottled water } \\
\hline Boiled & 13 & 15.5 & 29 & 17.4 & 42 & 16.7 \\
\hline Unboiled & 12 & 14.3 & 18 & 10.8 & 30 & 12.0 \\
\hline \multicolumn{7}{|l|}{ Total } \\
\hline Boiled & 48 & 57.1 & 130 & 77.8 & 178 & 70.9 \\
\hline Unboiled & 36 & 42.9 & 37 & 22.2 & 73 & 29.1 \\
\hline
\end{tabular}

${ }^{a} 8$ children were exclusively breastfed.

that was not boiled before drinking or used for preparation of meals compared with $22.2 \%$ in the unaffected group $\left(\chi^{2}-\right.$ test, $P<0.05)$.

Water from the hospital municipal source was tested 3 times. The results of direct examination and culture of water samples revealed that Aeromonas hydrophila was isolated all 3 times, cysts of Entamoeba histolytica were detected 2 times, while cysts of Giardia lamblia and Pseudomonas aeruginosa were detected 1 time each.
Among the 84 nosocomial diarrhoea cases, 71 (84.5\%) were given food (whether alone or as supplementary food), and, of these, 49 (69\%) were given home-prepared food, 8 (11\%) were given hospital-prepared food and $14(20 \%)$ consumed food from both sources.

Of the 15 sealed cans of formula milk (from 5 different brands), 4 cans were found to be contaminated. In 2 brands (Isomil and Sunny Baby) Ps. aeruginosa and Enterobacter aerogenes were cultured from $1 / 3$ cans and in
1 brand (Materna) Enterobacter aerogenes was cultured from $2 / 3$ cans. In the other 2 brands (Guigose and Dialac) no specimens were cultured from any of 3 cans.

\section{Contamination of children's personal objects}

Table 2 shows that the food containers of 55 diarrhoea cases (65.5\%) were not cleaned at least once before and after each meal compared with $21.1 \%$ of unaffected children $\left(\chi^{2}\right.$-test, $\left.P<0.01\right)$. Among the children wearing dirty

\begin{tabular}{|c|c|c|c|c|c|c|}
\hline \multirow[t]{2}{*}{ Object } & \multicolumn{2}{|c|}{$\begin{array}{l}\text { Children with nosocomial } \\
\text { diarrhoea }(n=84)\end{array}$} & \multicolumn{2}{|c|}{ Unaffected children $(n=175)$} & \multicolumn{2}{|c|}{ Total $(n=259)$} \\
\hline & No. & $\%$ & No. & $\%$ & No. & $\%$ \\
\hline \multicolumn{7}{|c|}{ Food containers } \\
\hline Clean & 29 & 34.5 & 138 & 78.9 & 167 & 64.5 \\
\hline Unclean & 55 & 65.5 & 37 & 21.1 & 92 & 35.5 \\
\hline \multicolumn{7}{|c|}{ Clothes \& bed sheets } \\
\hline Clean & 25 & 29.8 & 127 & 72.6 & 152 & 58.7 \\
\hline Unclean & 59 & 70.2 & 48 & 27.4 & 107 & 41.3 \\
\hline \multicolumn{7}{|l|}{ Pacifier } \\
\hline Not used & 32 & 38.1 & 73 & 41.7 & 105 & 40.5 \\
\hline Used & 52 & 61.9 & 102 & 58.3 & 154 & 59.5 \\
\hline
\end{tabular}




\begin{tabular}{|c|c|c|c|c|c|c|c|c|c|}
\hline \multirow{3}{*}{ Type of microorganism } & \multicolumn{9}{|c|}{ Microorganism found on: } \\
\hline & $\begin{array}{c}\text { Mother's } \\
\text { hands }\end{array}$ & Bottle teat & Pacifier & $\begin{array}{l}\text { Water } \\
\text { container }\end{array}$ & Bed sheet & $\begin{array}{l}\text { Mother's } \\
\text { clothes }\end{array}$ & Cannula & & \\
\hline & No. & No. & No. & No. & No. & No. & No. & No & $\%$ \\
\hline Escherichia coli & 9 & 4 & 2 & 1 & 11 & 10 & 0 & 37 & 9.8 \\
\hline Salmonella spp. & 3 & 1 & 0 & 2 & 1 & 0 & 0 & 7 & 1.8 \\
\hline Shigella spp. & 6 & 0 & 0 & 1 & 1 & 1 & 0 & 9 & 2.4 \\
\hline Pseudomonas aeruginosa & 11 & 15 & 12 & 21 & 7 & 4 & 2 & 72 & 19.0 \\
\hline Proteus spp. & 7 & 2 & 1 & 1 & 13 & 10 & - & 34 & 9.0 \\
\hline Enterobacter spp. & 11 & 21 & 14 & 9 & 18 & 21 & 2 & 96 & 25.3 \\
\hline Citrobacterspp. & 9 & 11 & 6 & 2 & 13 & 12 & 1 & 54 & 14.2 \\
\hline Aeromonas spp. & 3 & 2 & 6 & 19 & 2 & 3 & 4 & 39 & 10.3 \\
\hline Klebsiella spp. & 4 & 1 & 1 & 2 & 7 & 5 & 0 & 20 & 5.3 \\
\hline Serratia spp. & 2 & 1 & 0 & 0 & 2 & 3 & 0 & 8 & 2.1 \\
\hline Entameoba histolytica & 0 & 0 & 0 & 2 & 0 & 0 & 0 & 2 & 0.5 \\
\hline Giardia Lamblia & 0 & 0 & 0 & 1 & 0 & 0 & 0 & 1 & 0.3 \\
\hline Total & 65 & 58 & 42 & 61 & 75 & 69 & 9 & 379 & 100.0 \\
\hline
\end{tabular}

clothes and/or lying on bed sheets that were not washed periodically (or changed) every day during the hospital stay, 59 were diarrhoea cases $(70.2 \%)$ compared with 48 who were unaffected $(27.4 \%)\left(\chi^{2}\right.$-test, $\left.P<0.01\right)$. The use of a pacifier was noted in $52(61.9 \%)$ of diarrhoea patients and in 102 (58.3\%) of the unaffected group $\left(\chi^{2}\right.$-test, $P<$ 0.01 ).

Table 3 shows the results of swab cultures from different objects. A total of 379 organisms were cultured. The most frequently contaminated objects were bed sheets ( $19.8 \%$ of cultures) and the clothes and hands of the mothers ( $18.2 \%$ and $17.2 \%$ of cultures). The most commonly isolated species were
Enterobacter spp. (25.3\% of organisms identified) and Ps. aeruginosa (19.0\%).

Table 4 shows that out of 246 contaminated objects identified, 160 (65.0\%) were harbouring the same causative agent that was detected in the stool culture of the child and that this correlation was significant (analysis of variance, $P<0.01$ ). Microorganisms were identical to the child's in $48 / 54$ cases on bottle teats (88.9\%), in $21 / 26$ cases on pacifiers (80.8\%) and in 31/43 cases on mother's hands (72.1\%).

\section{Contamination among staff}

Cultures were made from swabs from the medical staff for identification of Gram-negative rods. Of 107 swabs taken from hands, oral cavities and stethoscopes Enterobacter spp., Citrobacter spp. and Proteus spp. were the most common bacteria isolated $(22.4 \%, 20.6 \%$ and $17.8 \%$ respectively, about $61 \%$ of the total isolates); other bacteria were less frequent. Hands were the most commonly contaminated objects ( $74 \%$ of swabs), followed by stethoscopes (14\%), while $12 \%$ of swabs showed contamination from the oral cavity of staff, mainly Enterobacter spp. and Citrobacter spp. The poorest hygienic practice was found among the 8 non-medical staff (cleaners, reception and administration staff) $(75 \%$ had contaminated hands, while the best was among 10 medical students (only $10 \%$ had contaminated hands).

\begin{tabular}{|c|c|c|c|c|c|c|c|c|c|}
\hline \multicolumn{10}{|c|}{$\begin{array}{l}\text { Table } 4 \text { Number of objects contaminated with microorganisms identical or non-identical to those found in the stool of } \\
\text { related cases of nosocomial diarrhoea ( } n=246 \text { objects) }\end{array}$} \\
\hline \multirow{3}{*}{$\begin{array}{l}\text { Microorganisms } \\
\text { isolated from } \\
\text { object and } \\
\text { child's stool }\end{array}$} & \multicolumn{9}{|c|}{ Contaminated object: } \\
\hline & $\begin{array}{l}\text { Mother's } \\
\text { hands }\end{array}$ & Bottle teat & Pacifier & $\begin{array}{l}\text { Water } \\
\text { container }\end{array}$ & Bedsheet & $\begin{array}{l}\text { Mother's } \\
\text { clothes }\end{array}$ & Cannula & & tal \\
\hline & No. & No. & No. & No. & No. & No. & No. & No. & $\%$ \\
\hline Identical & 31 & 48 & 21 & 17 & 27 & 16 & 0 & 160 & 65.0 \\
\hline Non-identical & 12 & 6 & 5 & 12 & 23 & 21 & 7 & 86 & 35.0 \\
\hline Total & 43 & 54 & 26 & 29 & 50 & 37 & 7 & 246 & 100.0 \\
\hline
\end{tabular}

Analysis of variance, $P<0.001$. 


\section{Contamination in the ward environment}

Table 5 shows the microorganisms isolated from floors, doorknobs and desks of 13 hospital rooms during different months of the study. The most commonly isolated Gram-negative rods were Enterobacter spp. (isolated from a peak of 8 rooms in January 2005), Citrobacter spp. and Pseudomonas spp. (each isolated from a peak of 7 and 6 rooms in July 2005). The lowest period for contamination was March 2005.

Ps. aeruginosa and Enterobacter spp., then Proteus spp. were the predominant bacteria isolated from the preparation room. Enterobacteriaceae and other Gram-negative rods were isolated from the ward toilets. The most commonly isolated organisms were Proteus spp. and $P$ s. aeruginosa (5 times each), $A$. hydrophila, Enterobacter spp. and Citrobacter spp. (4 times each), Escherichia coli (3 times), Klebsiella spp. and Shigella spp. (2 times) and Providencia rettgeri (1 time).

\section{Discussion}

Hospitals are now taking the problem of nosocomial infection very seriously and are taking steps to reduce it [6].

As the quality of drinking water in countries with limited resources is often unsafe, preventing patients from developing diarrhoea from contaminated water and controlling outbreaks of waterborne infectious diarrhoea are persistent problems [2]. In the current study, diarrhoea rates were significantly higher among children given unboiled water, regardless of the source of water supply used. This agrees with Quick et al.'s study in Bolivia [7].

Although there was a slightly higher prevalence of diarrhoea among children consuming food prepared in the hospital, this was not significant statistically. This may be due to the low age limit of the target group as they depended mainly on milk for feeding.

Hygiene measures in the hospital were generally poor, and were poorest among the families of children with infectious nosocomial diarrhoea. Our data show that bed sheets, clothes and mothers' hands were the objects most commonly contaminated with Gramnegative bacteria in children with nosocomial diarrhoea. This reflects the poor hygiene of the families as well as the hospital. For children with diarrhoea, a highly significant relationship was found between the types of microorganisms contaminating objects in contact with the child and in the child's faeces. This observation is in agreement with Esrey et al. who found in a community study in 8 developing countries that the overall level of faecal contamination in the environment and proper sanitation measures had a major impact on the prevalence of infectious diarrhoea [8]. In fact the impact of proper sanitation was greater than the effect of improving the water supply, as the benefits from improved water were only achieved when sanitation was also improved. Traore et al. in a study in Burkina Faso pointed out that it is not where the children defecate but what the mother does with the stool that is important [9].

Swab cultures obtained from the medical personnel revealed that the hands, oral cavities and stethoscopes of doctors and medical students were highly contaminated with Gramnegative bacteria. The poorest hygienic practice was found among the employees, while the best was among medical students. This is most likely due to the duration of contact with the hospital environment, which is longer in the case of the employees in comparison with medical students. Disinfectant materials should not be considered as trivial and mundane. Simple disinfection measures, including hand washing, have the most impact on the control of nosocomial infection [10]. Panhotra in India found that Enterobacter spp. were carried by the fingertips of $13.3 \%$ of medical personnel, especially nurses [11]; this compares with $10 \%$ in the current study. The World Health Organization and United Nations Children's Fund remind us that "the simple act of

\begin{tabular}{|c|c|c|c|c|c|c|c|}
\hline \multirow[t]{3}{*}{ Microorganism } & \multicolumn{7}{|c|}{ Rooms investigated in: } \\
\hline & $\begin{array}{l}\text { Nov. } \\
2004\end{array}$ & $\begin{array}{l}\text { Jan. } \\
2005\end{array}$ & $\begin{array}{l}\text { Mar. } \\
2005\end{array}$ & $\begin{array}{c}\text { May } \\
2005\end{array}$ & $\begin{array}{c}\text { Jul. } \\
2005\end{array}$ & & \\
\hline & No. & No. & No. & No. & No. & No. & $\%$ \\
\hline Enterobacter spp. & 7 & 8 & 2 & 7 & 7 & 6 & 46 \\
\hline Citrobacter spp. & 6 & 6 & 1 & 6 & 7 & 5 & 38 \\
\hline Pseudomonas spp. & 4 & 5 & 3 & 5 & 6 & 5 & 38 \\
\hline Proteus spp. & 3 & 4 & 2 & 3 & 2 & 3 & 23 \\
\hline Klebsiella spp. & 3 & 3 & 0 & 2 & 1 & 2 & 15 \\
\hline Serratia spp. & 1 & 2 & 0 & 1 & 1 & 1 & 8 \\
\hline Aeromonas spp. & 2 & 1 & 0 & 0 & 1 & 1 & 8 \\
\hline Escherichia coli & 1 & 1 & 0 & 0 & 1 & 1 & 8 \\
\hline
\end{tabular}


washing hands with soap and water can reduce diarrhoeal disease transmission by one-third" [12].

The most common Gram-negative bacteria isolated from objects were Enterobacter spp., Pseudomonas spp., Citrobacter spp., Aeromonas spp. and E. coli. Moreover, the first 3 species were the most commonly isolated organisms from the paediatric ward rooms including the floors, desks and doorknobs. The result is in agreement with Masaki et al. in geriatric wards in Japan [13].

Human milk provides optimal nutrition to the infant in addition to possessing protective properties [14]. A study in Nigeria found that only $35 \%$ of breastfed infants developed diarrhoea compared with about $75 \%$ of mixedfed and formula-fed infants [15]. Our results confirmed the role of human milk in preventing infection; only $26.2 \%$ of children $<2$ years who developed nosocomial diarrhoea were breastfeeding compared with $52.5 \%$ of the unaffected children.

Similarly, $52.5 \%$ of the children $<2$ years who developed nosocomial diarrhoea were bottle-fed in comparison to $24.8 \%$ of the unaffected children. Contamination was found in 4 out of 15 sealed cans of formula milk. Muytjens et al., in a study of 141 powdered breast milk substitutes from 28 countries, found that more than half (52\%) of the samples was contaminated with Gramnegative bacteria [16]. Many children in ourstudywere also being givenunboiled, contaminated water from their homes or from the hospital supply to drink or in prepared meals. Samples of water from the hospital municipal source were examined 3 times and the results indicated a low level of water chlorination that did not eradicate Gram-negative bacterial growth, and a bad filtration system that permitted G. lamblia cysts to pass, as these cysts are not killed by ordinary chlorination [17].

The rate of contamination in the paediatric ward dropped suddenly during March 2005 compared with that in January and February in the same year. This can be explained by the use of a disinfectant (chlorhexidine digluconate) by the hospital employees about 24 hours before the time of our periodic swabbing. Nevertheless, the following microbes were isolated during that period: Ps. aeruginosa, Proteus spp., Citrobacter spp. and Enterobacter spp. This indicates that these microorganisms are resistant to the disinfectant used routinely in the hospital. Pseudomonas spp., Enterobacter spp. and Proteus spp. were the commonest bacteria isolated from the preparation room, which reflects the poor cleaning practices and sanitation measures undertaken by both the nursing staff and other employees, as well as the high resistance of these bacteria and their adaptation to the disinfectants which are commonly used in the hospital.

Finally, observation of our children's ward, like many others in the Middle East, showed that it was often very crowded. This is because of the high admission rates, the fact that mothers always accompany their sick children and that there is free access for visitors. Children tend not to be restricted to their bed or to their room, which increases the risk of cross-infection. These are important factors responsible for the transmission of an infectious agent from the source to the host, and as a consequence, increase the risk of the spread of nosocomial infections, especially among children in the paediatric ward.

We recommend efforts to improve the personal hygiene of hospital staff and changing the hospital care practices to decrease sources of infection (e.g. changing dirty clothes, washing dirty containers, not allowing more than one family member to stay with the child), as well as the promotion of breastfeeding.

\section{References}

1. Bacterial diarrheal disease. In: Gillespie SH, Bamford KB, eds. Medical microbiology and infection at a glance. London, Blackwell, 2000.

2. Tietjen L, Bossemeyer D, McIntosh M, eds. Infection prevention guidelines for healthcare facilities with limited resources. Chapter 30. Preventing nosocomial infections. Baltimore, Maryland, Jhpiego and United States Agency for International Development, 2003.

3. Tortora GJ, Funke BR, Case CL. Microbiology: an introduction, 6th ed. California, Benjamin/Cummings, 1998.

4. Mims C et al., eds. Medical microbiology, 2nd ed. London, Mosby, 1998.

5. Uppal B, Wadhwa V, Mittal SK. Nosocomial diarrhea. Indian journal of pediatrics, 2004, 71:883-5.

6. Nosocomial infections and hospital-acquired illnesses-overview. Baltimore, Maryland, EHA Consulting Group, 2005 (http:// www.ehagroup.com/epidemiology/nosocomial-infections/, accessed 20 October 2009)
7. Quick R et al. Diarrhea prevention in Bolivia through point-ofuse disinfection and safe storage: a promising new strategy. Epidemiology of infection, 1999, 122:83-90.

8. Esrey SA. Water, waste and well-being: a multicountry study. American journal of epidemiology, 1996, 143(6):608-23.

9. Traore $\mathrm{E}$ et al. Child defecation behavior, stool disposal practice and childhood diarrhea in Burkina Faso: results from a case control study. Journal of epidemiology and community health, 1994, 48:270-5.

10. Lim VK. Disinfection and the control of nosocomial infection. Medical journal of Malaysia, 1995, 50(4):289-90.

11. Panhotra BR et al. Isolation and survival of gentamicin resistant Enterobacter aerogenes on finger tips of hospital personnel. Zentralblatt fur Hygiene und Umweltmedizin, 1989, 188 (3-4):331-5.

12. Joint monitoring program for water supply and sanitation: global water supply and sanitation assessment report. Geneva, World Health Organization/United Nations Children's Fund, 2000. 
13. Masaki $\mathrm{H}$ et al. [Detection of Gram-negative bacteria in patients and hospital environment at a room in geriatric wards under the infection control against MRSA]. Kansenshogaku zasshi, 2001, 75(2):144-50 [in Japanese].

14. Lawrence RA, Lawrence RM. Breastfeeding: a guide for the medical profession. St. Louis, Missouri, Mosby, 1999.

15. Scott-Emuakpor MM, Okafor UA. Comparative study of morbidity and mortality of breast-fed and bottle-fed Nigerian infants. East African medical journal, 1986, 63(7):452-7.
16. Muytjens HL, Roelofs-Willemse H, Jaspar GH. Quality of powdered substitutes for breast milk with regards to the family Enterobacteriaceae. Journal of clinical microbiology, 1988, 26(4):743-6.

17. Alleviating protein-energy malnutrition. World Health Organization [website] (https://apps.who.int/nut/pem.htm, accessed 20 October 2009).

\section{Clean Care is Safer Care}

Clean Care is Safer Care works in partnership with the global health community and others to ensure that sustained hand hygiene improvement remains on the national and international health agenda. Our aim is to ensure that infection control is acknowledged universally as a solid and essential basis for the attainment of patient safety, contributing to a significant, measurable reduction in the burden of disease attributable to health care-associated infections.

Information about Clean Care is Safer Care can be found at: http://www.who.int/gpsc/en/index.html 